\title{
The Effect of Probiotics on the Morphological Characteristics of the Small Intestinal Mucosa
}

\author{
Anna Rekiel ${ }^{1}$, Wojciech Bielecki², Justyna Więcek ${ }^{1}$ \\ ${ }^{1}$ Department of Animal Breeding, Faculty of Animal Science, Warsaw University of Life Sciences, Poland \\ ${ }^{2}$ Department of Pathology and Veterinary Diagnostics, Faculty of Veterinary Medicine, \\ Warsaw University of Life Sciences, Poland
}

Received April 8, 2009

Accepted September 21, 2010

\begin{abstract}
The objective of this study was to determine the impact of antibiotics and selected probiotics on the morphological properties of the small intestinal mucosa in growing-finishing pigs. Two production experiments were conducted on 32 hybrid fatteners ( 16 pigs per experiment, of 8 gilts and young hogs each, at a 1:1 ratio) fed complete diets in a 2-phase system. The animals were clinically healthy and had been treated for parasites prior to fattening. In the first experiment, diets were supplemented with the antibiotic flavomycin (group $\mathrm{C} 1$ ) and the probiotic ToyoCerin (Bacillus toyoi strain) (group E1) at the amount of $0.1 \%$, and in the second experiment with flavomycin (C2) and Bactocell (Pedicoccus acidilactici, MA18/5M strain) (E2) at the amount of $0.01 \%$. A histological analysis of small intestinal epithelial sections was performed using bax, bcl-x, bcl-2 polyclonal antibodies and Ki-67 and PCNA monoclonal antibodies. Sections of the duodenum, jejunum and ileum were prepared post mortem. Haematoxylin and eosin $\mathrm{H}-\mathrm{E}$, histochemical (PAS-Alcian Blue) and immunohistochemical staining procedures were applied. The results of histological, histochemical and immunohistochemical examinations of the small intestinal mucosa indicated that feed additives and probiotics had a varied effect on the morphological characteristics and the proliferation capacity of crypt epithelium. Enterocyte proliferation in crypt epithelium decreased after the administration of probiotics. The absence of significant differences between groups (C1-E1; C2-E2) may suggest that probiotics have no adverse effect on mucosal epithelial cells. Nevertheless, given the importance of this topic and the development of the use of feed additives, follow up research in this area is needed.
\end{abstract}

Feed additives, fatteners, small intestine, goblet cells, bax, bcl-x, bcl-2, PCNA, Ki-67

Nutritional factors and bacterial populations colonizing the gastrointestinal tract modify the intestinal microstructure (Vitini et al. 2000) and induce functional changes in the intestinal mucosa (Babinska et al. 2005). Researchers vary in their opinions on the probiotic effect of bacteria on the intestinal epithelium. Baum et al. (2002) and Budiño et al. (2005) demonstrated that Saccharomyces boulardii and Bacillus cereus var. Toyoi strains had a beneficial influence on the epithelial structure, crypt morphology, number of Ki-67 positive cells and total mucosal cell counts, including cells secreting acidic and neutral mucopolysaccharides. Reiter (2006) did not observe any changes in the small and large intestine as a result of the supplementation of diets fed to sows and piglets with Enterococcus faecium strains. Lodemann et al. (2006) found that probiotics had a positive effect on animals. The findings of Pérez-Conesa et al. (2007) who studied rats administered probiotics, prebiotics and synbiotics indicate that feed additives significantly modify the depth of crypts in the proximal and distal colonic segments, and improve calcium, magnesium and phosphorus absorption. Rekiel et al. (2005) and Rekiel and Gajewska (2006) reported that the components and fibre content of feed were capable of modifying intestinal microflora. According to Rekiel et al. (2007), selected feed additives differentiate the proliferative and apoptotic activity of crypt epithelium. The published results of studies conducted on pigs and rats point to the need for follow-up research in this area.

Address for correspondence:

Prof. dr hab. Anna Rekiel

Department of Animal Breeding

Faculty of Animal Sciences, Warsaw University of Life Sciences

Ciszewskiego 8, Warsaw 02-786, Poland
Phone: +480225936561

Fax: +48 0225936554

E-mail: anna_rekiel@sggw.pl

http://www.vfu.cz/acta-vet/actavet.htm 
The objective of this study was to determine the impact of antibiotics and selected probiotics on the morphological properties of the small intestinal epithelium in growingfinishing pigs.

\section{Materials and Methods}

Two production experiments were conducted on 32 hybrid fatteners (Polish Large White $\times$ Polish Landrace $\times$ Duroc) and (Polish Large White $\times$ Polish Landrace $x$ Belgian Landrace) divided into control and experimental groups C1 and E1 (experiment I) and C2 and E2 (experiment II), of 8 gilts and young hogs each (1:1). The animals were clinically healthy and had been treated for parasites prior to fattening by adding vermifugal to the feed. They were kept individually throughout the experiment. In a two-stage fattening process ( $\mathrm{I}-$ from $21 \pm 0.5 \mathrm{~kg}$ to $56 \pm 1 \mathrm{~kg}$, II - from $56 \pm 1 \mathrm{~kg}$ to $102 \pm 1 \mathrm{~kg}$ ), feed was dosed individually in line with the observed standards (Pig Nutrient Requirements 1993). Pigs of Group C1 and C2 were fed a complete diet supplemented with a 5\% premix containing flavomycin (100 mg per $\mathrm{kg}$ ), and pigs of group E1 and E2 were fed a premix without the antibiotic. At the first and second stage of fattening, group E1 pigs received mixed feed containing $0.1 \%$ of the probiotic ToyoCerin (Bacillus toyoi strain), and E2 group animals were administered mixed feed with the addition of $0.01 \%$ Bactocell (Pedicoccus acidilactici, strain MA18/5M).

The chemical compositions of raw materials in the feed were analyzed (AOAC 1990), and their nutritive value was determined. The energy value of diets administered at the first and second stage of fattening was 12.3 and 12.2 MJ ME/kg respectively (Pig Nutrient Requirements 1993), and the protein content of diets in experiment I was: $\mathrm{C} 1-159$ and $141 \mathrm{~g} / \mathrm{kg}, \mathrm{E} 1-158$ and $141 \mathrm{~g} / \mathrm{kg}$, and in experiment II, C2 - 165 and $143 \mathrm{~g} / \mathrm{kg}, \mathrm{E} 2-168 \mathrm{and}$ $145 \mathrm{~g} / \mathrm{kg}$.

The pigs were sacrificed at the completion of fattening in the $174^{\text {th }}$ day of life ( 8 pigs from each group; gilts to hogs - 1:1). The slaughter of fattening pigs was consistent with the current meat industry practices using electrical stunning. Duodenum, jejunum and ileum sections $(5 \times 20 \mathrm{~mm}$ each $)$ were sampled immediately after slaughter. Sections were rinsed with $0.9 \%$ saline, fixed with a $10 \%$ buffered formalin solution and paraffin-embedded (Paraplast ${ }^{\mathbb{B}}$ plus-Aldrich, USA). Paraffin blocks were microtome-cut into serial sections, $4 \mu \mathrm{m}$ in thickness. The sections were haematoxylin and eosin (HE) stained, and the presence of acidic and neutral mucopolysaccharides was investigated by histochemical staining (PAS-Alcian Blue). The presence of bax, bcl-x, bcl-2, PCNA and Ki-67 antigens was determined immunohistochemically. Polyclonal Rabbit Anti-Human Bax (bax), Polyclonal Rabbit Anti-Human Bcl-X (bcl-x), Monoclonal Mouse Anti-Human BCL2, Oncoprotein and Clone 124 (bcl-2) antibodies were used for in situ identification of apoptosis. Proliferation of epithelial cells was determined by a two-stage process (EnVision + ) with the use of monoclonal antibodies: Monoclonal Mouse Ant-Human Ki-67, Clone Ki-S5 (Ki-67), Monoclonal Mouse Anti-Proliferating Cell Nuclear Antigen (PCNA), Clone PC10 (PCNA). Samples were evaluated with a BX50 Olympus light microscope at $\times 400$ magnification.

Positive and negative reactions, including dispersed (bax, bcl-x, bcl-2) and countable (PCNA, Ki-67) labeling reactions, were determined in immunohistochemically stained samples. PCNA and Ki-67 positive cells were determined by counting up to 100 cells each time in three replications. The results are presented as means over replications. A similar approach was used to determine the percentage of goblet cells producing acidic or neutral mucopolysaccharides.

Additionally, infiltration of plasma cells, mast cells, lymphocytes, eosinophils, histiocytes by each morphological feature was evaluated.

The results were verified statistically by one-factorial analysis of variance with the use of the least squares method.

\section{Results}

Intense plasma cell infiltration in the stromal tissue of the duodenum and numerous or very numerous goblet cells in crypts were reported in the first experiment in group C1 (Table 1). Connective tissue proliferation was determined in the jejunal stroma, accompanied by intense mononuclear cell infiltration and the presence of mast cells. Few goblet cells were noted. The histological examination of ileum sections showed intense inflammatory infiltration with an equal share of plasma cells and histiocytes and a focal accumulation of eosinophilic granulocytes. Single mast cells were found. Heavy plasma cell infiltration was observed in the duodenal stroma (group E1) which could point to intensified immunoglobulin production (Table 1). A high number of goblet cells were found in crypt epithelium. Stroma proliferation was noted in the jejunum as a symptom of a productive process. There was an abundance of connective tissue fibres. Russell bodies were also found. Mononuclear cell infiltration with predominance of plasma cells was observed. Mononuclear cell infiltration was noted focally with the involvement of 
eosinophilic granulocytes. Connective tissue proliferation was observed in the stroma of the ileal mucosa, with a focal predominance of mononuclear cells and a high or moderate share of mast cells. A small number of eosinophilic granulocytes and plasma cells were also found.

In group E2 in the second experiment, the stroma of the duodenal mucosa showed a very high number of plasma and mast cells. Intense mononuclear cell infiltration was also noted. Mononuclear cell infiltration was observed in the jejunal mucosa with a focal accumulation of mast cells. Other mononuclear cells were also observed with a focal predominance of lymphoid cells. A high number of goblet cells were found in crypts. The ileal mucosa showed a high number of mononuclear cells with a predominance of plasmocytes and focal infiltrations of mostly mast cells. In the duodenal mucosa of group E2 pigs, mononuclear cell infiltrations were observed in the stroma, with a predominance of lymphoid cells and a focal accumulation of plasma cells (Table 1). Russell bodies were also present. A very high number of goblet cells were noted in crypt epithelium. Cellular infiltrations with the predominance of mononuclear cells, including mast cells, plasma cells and histiocytes, as well as single eosinophils were observed in the jejunal mucosa. Parts of the investigated material showed weak cellular infiltration with a predominance of mononuclear cells and a small focal share of mast cells. The stroma of the ileal mucosa showed mononuclear cell infiltrations with a high share of mast cells. Eosinophilic granulocytes and mononuclear cell infiltrations were also determined with a predominance of plasma cells. A high number of mast cells were observed (Table 1).

Table 1. Histological evaluation of cellular infiltration in the intestinal mucosa (H-E staining)

\begin{tabular}{|c|c|c|c|c|c|c|c|c|c|c|c|c|}
\hline \multirow{3}{*}{ Cells } & \multicolumn{6}{|c|}{ Experiment 1} & \multicolumn{6}{|c|}{ Experiment 2} \\
\hline & \multicolumn{2}{|c|}{ Duodenum } & \multicolumn{2}{|c|}{ Jejunum } & \multicolumn{2}{|c|}{ Ileum } & \multicolumn{2}{|c|}{ Duodenum } & \multicolumn{2}{|c|}{ Jejunum } & \multicolumn{2}{|c|}{ Ileum } \\
\hline & $\mathrm{C} 1$ & E1 & $\mathrm{C} 1$ & E1 & $\mathrm{C} 1$ & E1 & $\mathrm{C} 2$ & E2 & $\mathrm{C} 2$ & E2 & $\mathrm{C} 2$ & E2 \\
\hline Mononuclear & & $++* *$ & $+++* *$ & $++* *$ & & $++*$ & $++* *$ & $++* *$ & $++* *$ & $++* *$ & $++* *$ & $++*$ \\
\hline Plasma cells & $+++* * *$ & ++ & & ++ & $++* *$ & $+*$ & ++ & $+++* *$ & ++ & + & ++ & ++ \\
\hline Lymphocytes & & & & & & & & ++ & $++* *$ & + & & \\
\hline Histiocytes & & & & & ++ & & & & & + & & \\
\hline Mast cells & & + & + & & + & +++ & + & & ++ & & ++ & +++ \\
\hline Eosinophils & & & & ++ & +++ & + & & & + & + & & ++ \\
\hline
\end{tabular}

$\mathrm{C} 1, \mathrm{C} 2$ - control groups (flavomycin)

E - experimental groups: E1 - ToyoCerin, E2 - Bactocell

Cell presence: + moderate, ++ numerous, +++ very numerous (low, average, high)

Cellular infiltration: * moderate, $* *$ intense, $* * *$ highly intense

The share of goblet cells secreting acidic and neutral mucopolysaccharides did not differ between groups in both experiments (Table 2). A predominance of acidic mucopolysaccharides over neutral polysaccharides was noted in the duodenum and the jejunum, and a similar predominance was observed in the ileum in groups $\mathrm{C} 1$ and $\mathrm{C} 2$ where acidic mucopolysaccharides were present in smaller quantities than in groups E1 and E2 (Table 2, Plate I, Fig. 1).

The results of labelling with bax, bcl-x and bcl-2 antigens varied in the first experiment (Table 3). Positive reactions were weakly pronounced and were observed in a small number of crypts and in individual crypt cells. More numerous reactions were noted in the second experiment. Regardless of the investigated group (C1 and E1, C2 and E2), the observed reactions were often dispersed in both experiments.

In most cases, the percentage of Ki-67 positive and PCNA positive cells did not differ significantly between control and experimental groups in both experiments (Table 4, Plate I, Fig. 2). In group E2, a significantly $(P \leq 0.01)$ lower percentage $(37.8 \%)$ of Ki-67 
Table 2. Presence of goblet cells in intestinal crypts (PAS Alcian Blue)

\begin{tabular}{|c|c|c|c|c|c|c|c|c|c|}
\hline \multirow{3}{*}{ Mucopolysaccharides } & \multicolumn{9}{|c|}{ Experiment 1} \\
\hline & \multicolumn{3}{|c|}{ Duodenum } & \multicolumn{3}{|c|}{ Jejunum } & \multicolumn{3}{|c|}{ Ileum } \\
\hline & $\mathrm{C} 1$ & E2 & SE & $\mathrm{C} 1$ & E2 & SE & $\mathrm{C} 1$ & E1 & SE \\
\hline Acidic & 98.83 & 97.17 & \multirow{2}{*}{1.040} & 98.17 & 99.42 & \multirow{2}{*}{0.827} & 93.00 & 88.25 & \multirow{2}{*}{4.043} \\
\hline \multirow[t]{4}{*}{ Neutral } & 1.17 & 2.83 & & 1.83 & 0.58 & & 7.00 & 11.75 & \\
\hline & \multicolumn{9}{|c|}{ Experiment 2} \\
\hline & \multicolumn{3}{|c|}{ Duodenum } & \multicolumn{3}{|c|}{ Jejunum } & \multicolumn{3}{|c|}{ Ileum } \\
\hline & $\mathrm{C} 2$ & E2 & SE & $\mathrm{C} 2$ & E2 & SE & $\mathrm{C} 2$ & E2 & SE \\
\hline Acidic & 98.25 & 99.83 & \multirow{2}{*}{0.754} & 98.33 & 99.75 & \multirow{2}{*}{0.496} & 86.00 & 100.00 & \multirow{2}{*}{5.433} \\
\hline Neutral & 1.75 & 0.17 & & 1.67 & 0.25 & & 14.00 & 0.00 & \\
\hline
\end{tabular}

$\mathrm{C} 1, \mathrm{C} 2$ - control groups (flavomycin)

E - experimental groups: E1 - ToyoCerin, E2 - Bactocell

Table 3. Evaluation of enterocyte apoptosis in intestinal crypts (percentage of reactions)

\begin{tabular}{|c|c|c|c|c|c|c|c|c|c|c|c|c|}
\hline \multirow{4}{*}{ Antibody } & \multicolumn{12}{|c|}{ Experiment 1} \\
\hline & \multicolumn{4}{|c|}{ Duodenum } & \multicolumn{4}{|c|}{ Jejunum } & \multicolumn{4}{|c|}{ Ileum } \\
\hline & \multicolumn{2}{|c|}{$\mathrm{Cl}$} & \multicolumn{2}{|c|}{ E1 } & \multicolumn{2}{|c|}{$\mathrm{Cl}$} & \multicolumn{2}{|c|}{ E1 } & \multicolumn{2}{|c|}{$\mathrm{Cl}$} & \multicolumn{2}{|c|}{ E1 } \\
\hline & + & - & + & - & + & - & + & - & + & - & + & - \\
\hline Bax & 25 & 75 & 25 & 75 & 25 & 75 & 75 & 25 & 75 & 25 & 50 & 50 \\
\hline Bcl-x & 0 & 100 & 0 & 100 & 0 & 100 & 0 & 100 & 0 & 100 & 0 & 100 \\
\hline \multirow[t]{5}{*}{ Bcl-2 } & 0 & 100 & 25 & 75 & 25 & 75 & 25 & 75 & 0 & 100 & 0 & 100 \\
\hline & \multicolumn{12}{|c|}{ Experiment 2} \\
\hline & \multicolumn{4}{|c|}{ Duodenum } & \multicolumn{4}{|c|}{ Jejunum } & \multicolumn{4}{|c|}{ Ileum } \\
\hline & \multicolumn{2}{|c|}{$\mathrm{C} 2$} & \multicolumn{2}{|c|}{ E2 } & \multicolumn{2}{|c|}{$\mathrm{C} 2$} & \multicolumn{2}{|c|}{ E2 } & \multicolumn{2}{|c|}{$\mathrm{C} 2$} & \multicolumn{2}{|c|}{ E2 } \\
\hline & + & - & + & - & + & - & + & - & + & - & + & - \\
\hline Bax & 0 & 100 & 50 & 50 & 0 & 100 & 75 & 25 & 50 & 50 & 50 & 50 \\
\hline Bcl-x & 0 & 100 & 50 & 50 & 0 & 100 & 25 & 75 & 0 & 100 & 0 & 100 \\
\hline Bcl-2 & 25 & 75 & 50 & 50 & 50 & 50 & 100 & 0 & 50 & 50 & 50 & 50 \\
\hline
\end{tabular}

$\mathrm{C} 1, \mathrm{C} 2$ - control groups (flavomycin)

E- experimental groups: E1 - ToyoCerin, E2 - Bactocell

Reaction: + positive, - negative

Table 4. Evaluation of the proliferative capacity of enterocytes in intestinal crypts (percentage of positive reactions)

\begin{tabular}{|c|c|c|c|c|c|c|c|c|c|}
\hline \multirow{3}{*}{ Antibody } & \multicolumn{9}{|c|}{ Experiment 1} \\
\hline & \multicolumn{3}{|c|}{ Duodenum } & \multicolumn{3}{|c|}{ Jejunum } & \multicolumn{3}{|c|}{ Ileum } \\
\hline & $\mathrm{C} 1$ & E2 & SE & $\mathrm{Cl}$ & E2 & $\mathrm{SE}$ & $\mathrm{C} 1$ & E1 & SE \\
\hline Ki-S5/ Ki-67 positive cells & 47.58 & 56.58 & 2.801 & 50.67 & 44.33 & 2.713 & 48.11 & 36.75 & 4.931 \\
\hline \multirow[t]{4}{*}{ PC10/ PCNA positive cells } & 71.75 & 65.08 & 1.866 & 69.00 & 60.67 & 2.298 & 50.92 & 58.67 & 2.791 \\
\hline & \multicolumn{9}{|c|}{ Experiment 2} \\
\hline & \multicolumn{3}{|c|}{ Duodenum } & \multicolumn{3}{|c|}{ Jejunum } & \multicolumn{3}{|c|}{ Ileum } \\
\hline & $\mathrm{C} 2$ & E2 & SE & $\mathrm{C} 2$ & E2 & SE & $\mathrm{C} 2$ & E2 & SE \\
\hline Ki-S5/ Ki-67 positive cells & 49.33 & 49.08 & 3.415 & $56.92 \mathrm{~A}$ & $35.43 \mathrm{~B}$ & 2.605 & 44.83 & 49.75 & 3.727 \\
\hline $\mathrm{PC10/PCNA}$ positive cells & 77.42 & 70.42 & 2.681 & 73.08 & 65.50 & 2.758 & $67.17 \mathrm{~A}$ & $48.83 \mathrm{~B}$ & 2.988 \\
\hline
\end{tabular}

$\mathrm{C} 1, \mathrm{C} 2$ - control groups (flavomycin)

$\mathrm{E}$ - experimental groups: E1 - ToyoCerin, E2 - Bactocell

A, B - significant difference at $P \leq 0.01$ 
positive cells were found in the jejunum, and a significantly $(P \leq 0.01)$ lower percentage $(27.3 \%)$ of PCNA positive cells were found in the ileum than in group C2 only in the second experiment.

\section{Discussion}

In a study investigating weaned piglets, Budiño et al. (2005) administered a feed without additives and a feed containing an antibiotic, a probiotic, a prebiotic and a synbiotic to discover that the density and length of duodenal villi was higher in pigs fed a diet with the prebiotic than in those receiving a diet with the probiotic. The above authors also concluded that in comparison to diets containing other additives, the structure and efficiency of intestinal villi were restored at a much faster rate in pigs administered the probiotic. Reiter (2006) observed no effect of the supplementation of diets for sows and piglets with a probiotic (Enterococcus faecium SF 68 NIMB 10415) on the morphology of the small intestine in young pigs. Nutritional factors, such as short-chain organic acids derived from, e.g., oligosaccharides (Ruppin et al. 1980 as cited in Sawosz et al. 1997), may indirectly affect intestinal morphology, stimulating the proliferation of intestinal epithelial cells (Sakata et al. 1995; Ichikawa et al. 2002). In studies involving Lactobacillus acidophilus and Bifidobacterium spp., Babinska et al. (2005) found that probiotic strains had no adverse effect on the morphology of the digestive tract, liver and pancreas. Changes in glucose absorption were reported in young growing pigs fed a probiotic-supplemented diet (Lodemann et al. 2006). The administration of probiotic strains enhanced glucose absorption. The authors are of the opinion that the above results confirm the positive effect of probiotics on animals.

Apoptosis and proliferation can be determined in the intestinal epithelium by immunohistochemical methods (Reed 1994; Kelman 1997). The Ki-67 monoclonal antibody facilitates the labelling of proliferating cells, and it is used to determine the presence of the Ki-67 antigen, for example in healthy tissues. Ki-67 antigen expression is observed during all phases of the cell cycle $\left(\mathrm{G}_{1}, \mathrm{~S}, \mathrm{G}_{2}\right.$ and $\mathrm{M}$ phase), and it does not take place in the quiescent $\left(\mathrm{G}_{0}\right)$ phase and in inactive cells. The antigen is decomposed when the cell enters the non-proliferative state (Scholzen and Gerdes 2000).

The PCNA monoclonal antibody facilitates the labelling of proliferating cells in healthy tissues (Hall 1990). This protein expression is observed at the final stage of $\mathrm{G}_{1}$ phase and at the initial stage of S phase. PCNA significantly contributes to the continuity of the cell cycle. Oligonucleotides directed against PCNA inhibit the transition of cells to phase S of the cell cycle. PCNA plays an important role in the life and death of cells, being an element of the DNA replication and repair mechanism. The absence or the low level of functional PCNA may lead to cell apoptosis (Kelman 1997; Paunesku et al. 2001). In cells marked with this antibody, staining is nearly completely limited to the nucleus, it occurs in diffused, granular or mixed form (Hall 1990). A histometrical and immunohistochemical (PCNA) evaluation after the application of L-glutamine and/or nucleotides has shown that supplementation exerts a beneficial effect on the morphological and functional properties of intestinal mucosa (Domeneghini et al. 2004). Short-chain fatty acids were found to stimulate the proliferation of epithelial cells to a various degree: $n$-butyric acid $>$ propionic acid $>$ acetic acid. The source of those acids may be the fermentation process, but they can also be administered orally, or by intravenous, gastric and intestinal infusion (Sakata et al. 1995). In an experiment conducted on rats fed seven different diets supplemented with synbiotics, prebiotics (from the galactooligosaccharides group) and probiotics (Bifidobacterium bifidum and Bifidobacterium longum), Pérez-Conesa et al. (2007) reported significantly greater crypt depth in the proximal and middle segments of the large intestine.

A histological, histochemical and immunohistochemical evaluation of the small 
intestinal mucosa of fatteners whose diets were supplemented with an antibiotic and a probiotic indicated that the additives had a varied effect on the morphological properties and the proliferation capacity of crypt epithelium. Decreased enterocyte proliferation in crypt epithelium following the administration of probiotics necessitates further research in this area, although the absence of significant differences between groups may suggest that probiotics have no adverse effect on mucosal epithelial cells.

\section{Acknowledgments}

The study was supported by the Committee for Scientific (KBN) (Project No. P06Z 026 25).

\section{References}

Babinska I, Rotkiewicz T, Otrocka-Domagała I 2005: The effect of Lactobacillus acidophilus and Bifidobacterium spp. Administration on the morphology of the gastrointestinal tract, liver and pancreas in piglets. Pol J Vet Sci 8: $29-35$

Baum B, Liebler-Tenorio EM, -L En $\beta$ M, Pohlenz JF, Breves G 2002: Saccharomyces Boulardii and Bacillus cereus var. touoi influence the morphologie and the mucins of the intestine of pigs. Z Gastroenterol 40: 277-284

Budiño FEL, Thomaz MC, Kronka RN, Nakaghi LSO, Tucci FIN, Fraga AL, Scandolera AJ, Huaynate RAR 2005: Effect of probiotic and prebiotic inclusion in weaned piglet diets on structure and ultra-structure of small intestine. Braz Arch Biol Technol 48: 921-929

Davis ME, Brown DC, Maxwell CV, Rehberger T, Touchette KJ, Coalson JA 2003: Influence of Lactobacillus brevis $1 \mathrm{E}-1$ on the gastrointestinal microflora, gut morphology, and pig performance pre- and post-weaning. $9^{\text {th }}$ International Symposium on Digestive Physiology in Pigs. Banff, AB, Canada 2: 265-267

Domeneghini C, Di Giancamillo A, Savoini G, Paratte R, Bontempo V, Dell'orto V 2004: Structural patterns of swine ileal mucosa following L-glutamine and nucleotide administration during the weaning period. An histochemical and histometrical study. Histol Histopathol 19: 49-58

Hall PA, Levison DA, Woodds AL, Yu CC-W, Kellock DB, Watkins JA, Barnes DM, Gillett CE, Camplejohn R, Dover R, Waseem NH, Lane DP 1990: Proliferating cell nuclear antigen (PCNA) immunolocalization in paraffin sections: An index of cell proliferation with evidence of deregulated expression in some, neoplasms. J Pathol 162: 285-294

Ichikawa H, Shineha R, Satomi S, Sakata T 2002: Gastric or recital instillation of short-chain fatty AIDS stimulates epithelial cell proliferation on small land large intestine in rats. Dig Dis Sci 47: 1141-1146

Kelman Z 1997: PCNA: structure, functions and interactions [Review]. Oncogene 14: 629-640

Lodemann U, Hubener K, Jansen N, Martens H 2006: Effect of Enterococcus faecium NCIMB 10415 as probiotic supplement on intestinal transport and barrier function of piglets. Arch Anim Nutr 60: 35-48

Pérez-Conesa D, Lopez G, Ros G 2007: Effects of probiotic, prebiotic and synbiotic follow-up infant formulas on large intestine morphology and bone mineralisation in rats. J Sci Food Agricult 6: 1059-1068

Reed JC 1994: Mini-review: Bcl-2 and the regulation on programmed cell death. J Cell Biol 124: 1-6

Reiter K 2006: Effects of the probiotic Enterococcus faecium SF 68 (NIMB 10415) on the morphology of the intestinal mucosa of pigs. PhD Thesis. FU Berlin.

Rekiel A, Gajewska J 2006: Changes in the intestinal microflora of fatteners, as affected by the selected nutritional factors. Medycyna Wet 62: 925-930

Rekiel A, Gajewska J, Topol K, Sawosz E 2005: Effect of intensity of feeding on the intestinal microflora of pigs. Pol J Microb 54: 331-334

Rekiel A, Więcek J, Bielecki W, Gajewska J, Kulisiewicz J, Cichowicz M, Batorska M, Roszkowski T, Beyga K 2007: Effect of addition of feed antibiotic flavomycin or prebiotic BIO-MOS on production results of fatteners, blood biochemical parameters, morphometric indices of intestine and composition of microflora. Arch Tierz, Dummerstorf 50 Special Issue 172-180

Sakata T, Adachi M, Hashida M, Sato N, Kojima T 1995. Effect of n-butyric acid on epithelial cell proliferation of pig colonic mucosa in short-term culture. Deut Tierärztl Woch 102: 163-164

Sawosz E, Chachułowa J, Lechowski R, Binek M, Fiedorowicz S 1997: The influence of manno-oligosaccharide and lactic acid bacteria on plasma lipids level in pigs. Konf Nauk. Współczesne zasady zywienia świń. Jabłonna 3-4. czerwca. 145-147

Scholzen T, Gerdes J 2000: The Ki-67 protein: from the know and the unknown [review]. J Cell Physiol 182: 311-322

Vitini E, Alvarez S, Medina M, Medici M, de Budeguer MV, Perdigon G 2000: Gut mucosal immunostimulation by lactic acid bacteria. Biocell 24: 223-232 
Plate I

Rekiel A. et al.: The effect ... pp. 519-524

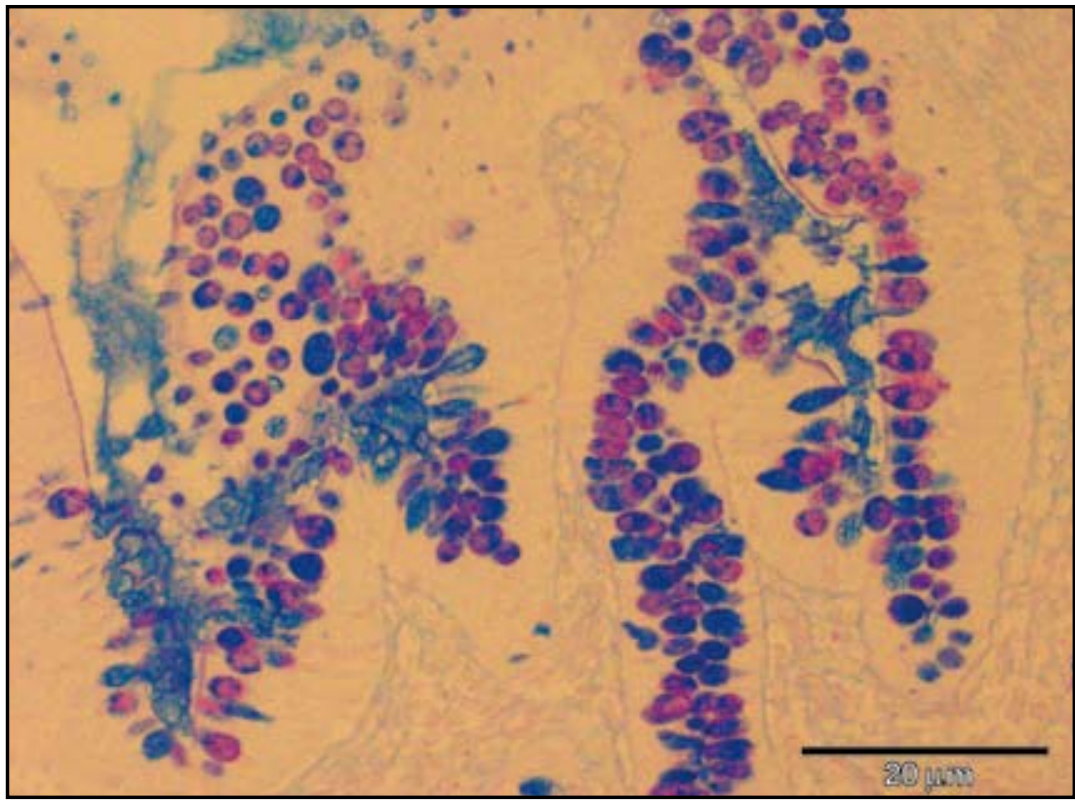

Fig. 1. Presence of PAS-Alcjan positive cells in ileum mucosa of C2 group. $\times 100$ magnification

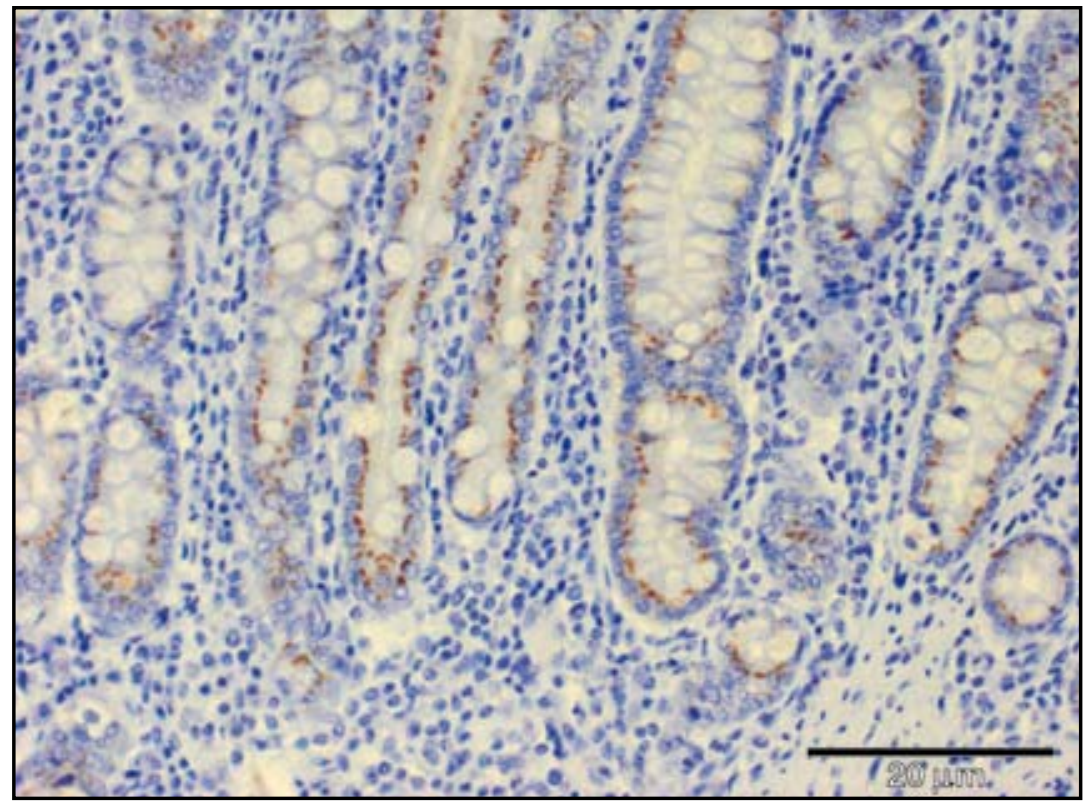

Fig. 2. Presence of Ki-67 positive cells in duodenum mucosa of E1 group. $\times 100$ magnification 